\title{
Indoor Air Quality in Steel Making Industries
}

\author{
Kamel K. Al-Zboon (Corresponding author) \\ Department of Environmental Engineering, Al-Balqa Applied University, Irbid, Jordan \\ Tel: 962-777-426-557_E-mail: Kalzboon@yahoo.com
}

\author{
Osric Tening Forton \\ Safeguards and Compliance Department (SNSC) \\ African Development Bank Group. Avenue Joseph Anoma \\ 01 BP 1387 Abidjan 01, Côte d'Ivoire
}

Received: December 4, 2018 Accepted: February 1, 2019 Published: February 4, 2018

doi:10.5296/emsd.v8i1.14315 URL: https://doi.org/10.5296/emsd.v8i1.14315

\begin{abstract}
Steel making industry is one of the major contributors to the global environmental catastrophes including climate change, photochemical smog and depletion of the ozone layer. Emissions from steel making process result in health impacts on workers and the neighboring communities. This study aimed to investigate indoor air quality in a steel making industry in Saudi Arabia. Indicative pollutants, $\mathrm{SO}_{2}, \mathrm{NOx}, \mathrm{CO}, \mathrm{CO}_{2}, \mathrm{O}_{3}, \mathrm{PM}_{10}$ and $\mathrm{PM}_{2.5}$ were measured at eight locations across the factory. The obtained results indicated that loading, melting, slag pouring and casting stages are the major sources of indoor air pollution. In comparison with the ambient air, indoor concentrations increased up to: 13.50, 9.8, 1.29, 2.7, 15.6, times for $\mathrm{SO}_{2}, \mathrm{NOx}, \mathrm{CO}_{2}$, VOCs, $\mathrm{O}_{3}$, respectively. Periodical medical check, pollution control, using of uncontaminated scrap, compliance with $H \& S$ regulations, are the key factors in reducing indoor emissions and subsequently improve occupational health.
\end{abstract}

Keywords: Air Pollution, Indoor Air Quality, Steel Industry, Occupational Health, Workplace

\section{Introduction}

Air pollution (indoor or outdoor) has negative effects on human health and environmental receptors (Salama and Berekaa, 2016). A significant correlation between long-term exposure (years) or short term exposure (several days) to air pollutants and adverse health effects has been reported. Health effects include: respiratory, neurological, cardiovascular diseases, irritation, cancer and cardiopulmonary mortality (Awad et al., 2016, Alharbi et al., 2014, 
Chaurasia and Tiwari, 2016, Al-zboon, 2017). Globally, an estimated 7 million people die because of exposure to high level of indoor and ambient air pollution including particulate matter $\left(\mathrm{PM}_{2.5}, \mathrm{PM}_{10}\right)$ and gaseous air pollutants $\left(\mathrm{O}_{3}, \mathrm{CO}, \mathrm{NO}_{2}, \mathrm{SO}_{2}\right.$ and $\left.\mathrm{H}_{2} \mathrm{~S}\right)$ (Jiang et al., 2016). Poor indoor air quality has been associated with building related illnesses such as headaches, fatigue, eye, and skin irritations (El-Sharkawy et al., 2014). In the industrial sector, indoor air pollution is considered one of the main causes of work-related diseases, and it is the major concern of the employers as well as the employees. In addition to its effect on human health and the environment, poor air quality affects the employees' comfortability and their productivity. As such, air pollution control is very important not only for the personnel health, but to achieve high employee productivity which will be reflected on the running costs and profits.

Concerted efforts have been made in developed countries to develop systems and processes, including standards against which evidence of indoor or outdoor pollution can be monitored and mitigation measures implemented for a wide range of industrial sectors.

Steel is one of the most widely used materials with annual production of 1.6 billion metric tons and the most recycled material in the world, making significant contributions to the gross domestic products (GDP) of the producing countries (UKSTEEL, 2018). More than 73\% of the global steel production is produced by using oxygen blown converter (OBC) method, $25.7 \%$ by electrical arc furnace (EAF), and less than $1 \%$ by other methods(WSA, 2017). Steel making is a highly energy intensive process and every stage of the process has potential sources of the air pollutants which may have high effects on the employees' health.

Steel making is associated with the emissions of air pollutants into the ambient environment including $\mathrm{PM}_{10}, \mathrm{SO}_{2}, \mathrm{NO}_{2}, \mathrm{O}_{3}$ and $\mathrm{CO}_{2}$ resulting in increased the risk of cardiovascular mortality, effect on pulmonary and cardiovascular function (Jena et al., 2011, EPRI, 2000, Shutt et al., 2017 ). Valenti et al. (2016), reported that $28 \%$ of the sample population living around the steel plants in Brazil suffer from respiratory pathologies (Valenti et al., 2016). Lung function survey of steel factory workers showed a linear correlation between lung function indices and the accumulative respirable metal dust (Co, Cr, Ni) (Hamzah et al., 2016).

Indoor air quality is one of the environmental components most affected by emissions from steel production. Steel industry hazards includes: mineral dusts, metal fumes, combustion gases, resin bonding systems, physical noise, heat and vibration. It has been reported that the steel industry is responsible for many occupational diseases such as: headache, eyes and noise irritation, irritability of respiratory system, bronchitis, asthma, cardiovascular, fatigue and dehydration (Khullar and Gupta, 2017). The steel industry had evolved significantly over the decades with progressive technical developments improving the production process, including process changes from heavily to less polluting processes (Jena et al., 2011). These changes coupled with improvements in environmental regulations have resulted in improved air quality in the steel plants.

While there are much ongoing researches regarding the impact of the steel industries on the ambient air quality, there has been limited research relating to indoor air quality and workers' 
health.

In order to develop and implement efficient mitigation measures, taking all necessary precautions to protect the health and safety of staff and others working within steel industries, it is important to understand the levels of common pollutants within steel factories in order to make informed decisions about environmental improvement.

In this paper we assess indoor air pollution from an electrical arc furnace steel smelting plant in Saudi Arabia. The results obtained from the study were interpreted in relation to potential human health risks and present a series of recommendations for improvements based on lessons learned from other parts of the world or other sectors.

\section{Methodology}

A steel making plant located in Riyadh, the capital of KSA was selected to investigate indoor air quality and possible effect on workers' health. This plant uses an electric arc furnace (EAF) with alkaline lining for steel pellets production. The raw material for steel making is mainly the scrap steel in addition to direct reduced iron, iron carbide, and pig iron. The production process includes: materials charging, melting, refining, slagging, tapping, secondary metallurgy, continuous casting, and cooling. The final products are pellets which are subjected to further production operations based on their final use.

Within the plant, samples were collected in the main sites where high emissions have typically been expected. The selected samples locations were from: the scrap area (N.1), loading area (N.2), melting area (N.3), casting area (N.4), slag pouring area (N.5) and the final products area (N.6). As a control, one sample (N.7) collected from the ambient environment outside the plant as a reference.

Data was collected using advanceSenso prob. made by Greywolf. The instrument is capable of measuring the emissions of $\mathrm{CO}, \mathrm{CO}_{2}, \mathrm{SO}_{2}, \mathrm{H}_{2} \mathrm{~S}, \mathrm{NO}_{2}, \mathrm{NH}_{3}, \mathrm{O}_{3}, \mathrm{VOC}_{\mathrm{s}}$, humidity and temperature. Measurement can be taken for short time (walkover) or for long time (weeks). In this study, indoor air pollutants were measured every one min utilizing grab sampling technique during three successive operational days. The instrument was installed on a triangular stand at a height of approximately $1.5 \mathrm{~m}$, with more than $2 \mathrm{~m}$ away from the nearest obstacles to avoid any potential interference during sampling (Muhamad-Darus et al., 2011). Particulate matters ( $\mathrm{PM}_{10}, \mathrm{PM}_{2.5}$, and TSP) were measured using dust profiler from Aeroqual. All instruments were calibrated before used.

\section{Results and Discussions}

\subsection{Concentration of $\mathrm{SO}_{2}$}

Sulfur dioxide is a very important air pollutant has taken significant concern by researchers due to its high impact on the environment especially in the formation of acid rain phenomenon. About half of the produced sulfur dioxide in the steel industry is caused by oxidation of sulfur during sintering and pelleting process.

The concentration of $\mathrm{SO}_{2}$ ranged from 0.02 at the cooling area to $0.27 \mathrm{ppm}$ at the furnace area 


\section{Macrothink}

(melting) as shown in Figure 1. Also, the loading and the casting areas have high concentration ( 0.22 and $0.18 \mathrm{ppm}$ respectively) indicating high increase in comparison with the ambient level of 0.02ppm. The potential sources of sulfur in EAF process include: charging of raw materials (mainly scraps), others auxiliary materials, and the first fusion pig iron (Iluțiu - Varvara et al., 2013).

Regarding its effect on workers' health, a concentration of 5 ppm may increase the resistance of airways, 10ppm cause high irritation of throat, nose, and eyes, and may cause paralysis and death at higher concentration $(>20 \mathrm{ppm})$ with long exposure period (Iluțiu - Varvara et al., 2013). Australian government limited $\mathrm{SO} 2$ in the workplace at 2ppm for 8-Hour Time-Weighted Average (TWA) and 5ppm for an exposure period of $15 \mathrm{~min}$ (Short term exposure limit, STEL) (SWU, 2018). The measured values are far below the reported harmful level, so no health effect might be expected.

It worth mentioning here that there is no confined space in the process lines and all production areas are connected spatially provides high dilution of pollutant between all areas, inside and outside the plant which may resulted in a reduction of concentration in some areas and increase it in other areas.

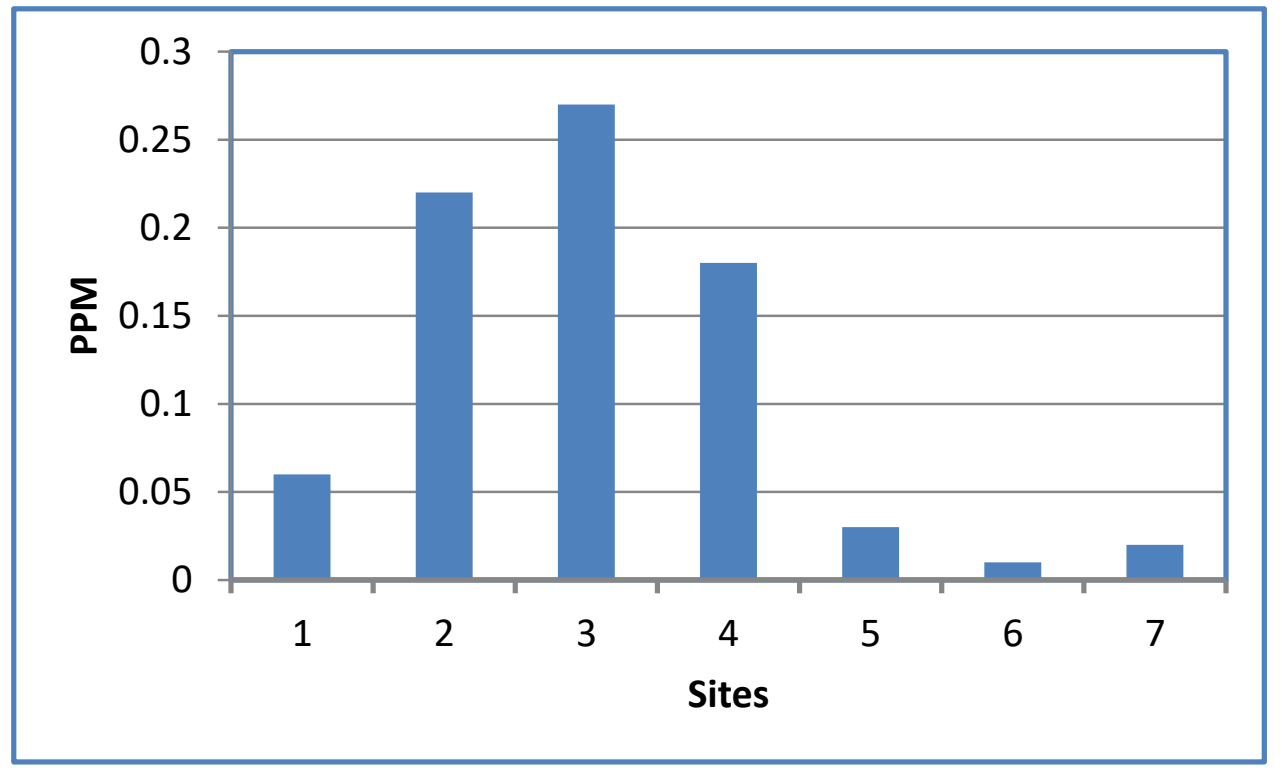

Figure 1. SO2 concentration

\subsection{Concentration of $\mathrm{NO}_{2}$}

At high temperature, combustion process generates NOx emissions which have significant impact on the environment including its contribution to smog and acid rain formation (Chan et al., 2004).

It has been reported that in addition of $\mathrm{CO} 2, \mathrm{NOx}$ is the second most detected pollutant gas in EAF with production rate of $0.12-0.32 \mathrm{~kg} / \mathrm{t}$ (Echterhof and Pfeifer, 2011). It is generated due 


\section{Macrothink}

to the oxidation of $\mathrm{N} 2$ in the atmosphere at high temperature and due to oxidation of nitrogen compounds in used fuel or due to the reaction of nitrogen radical with hydrocarbons. However due to the high temperature in the EAF, thermal mechanism is the predominant for of creating $\operatorname{NOx}($ Chan et al., 2004, Kirschen et al., 2005). NOx health effect is the focus of all health and safety agencies worldwide; for example department of Employment, Economic Development and Innovation in Queensland government (DEEDI) pointed out that the average level of exposure should be $<3 \mathrm{ppm}$ during the working day, while a level of 20ppm has immediate dangers to life and health. Health effects include: irritation of airways, eye, throat, and lungs, trigger asthma and pulmonary edema (DEEDI, 2018).

In our survey, the concentration of NO2 ranged from 0.07 at the scrap yard to $0.49 \mathrm{ppm}$ at the furnace area in comparison with 0.05 at the ambient air (Figure 2). Also significant levels were detected in the loading, casting and slag pouring areas, while lower level was in the cooling area. At the furnace area, NO2 is generated via two processes, start-up of the melting process, and through post combustion of carbon oxides and hydrogen inside and outside the furnace (Kirschen et al., 2005). SWU limited $\mathrm{NO}_{2}$ concentration at 3 and 5 for TWA and STEL respectively. Lower level of measured NO2 in comparison with SWU guidelines indicated that no health effects were expected (SWU, 2018).

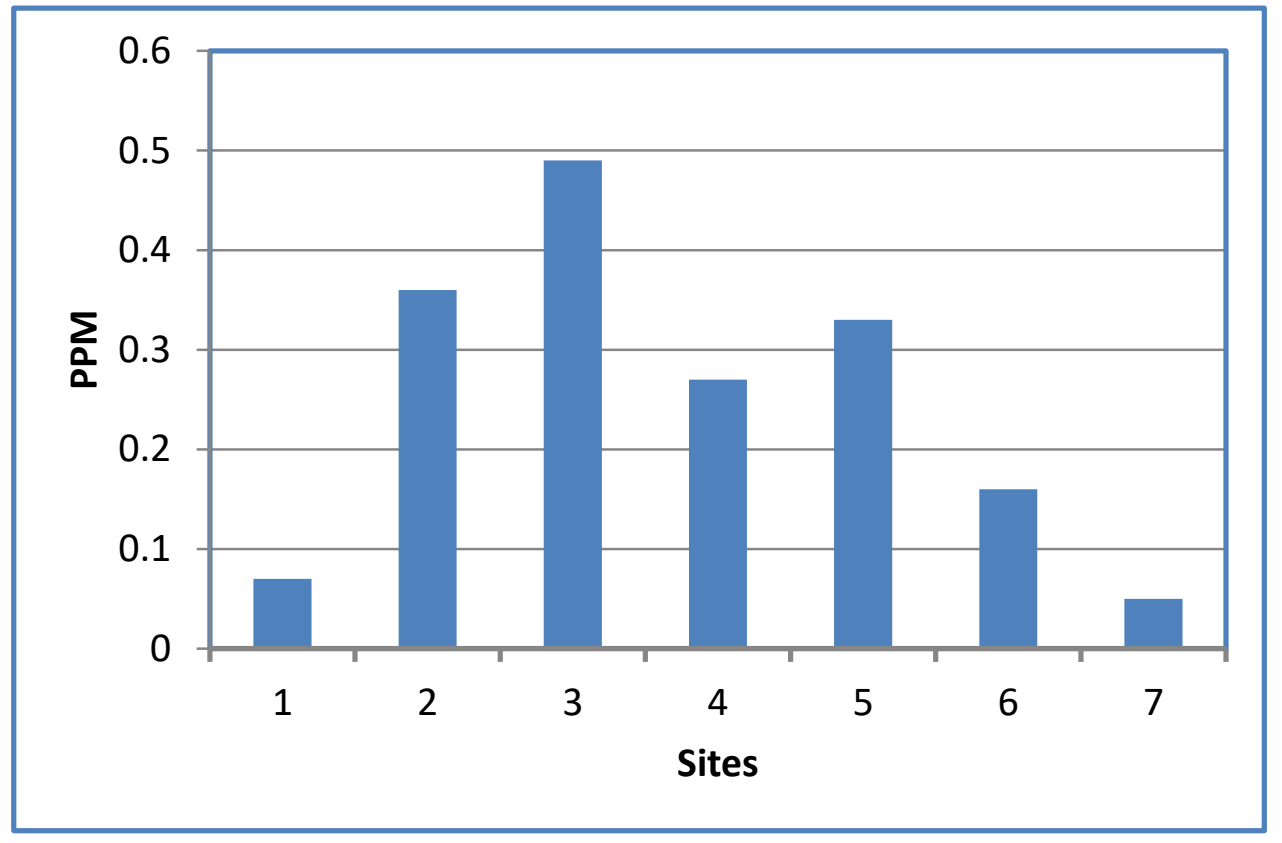

Figure 2. NO2 concentration

\subsection{Concentration of VOCs}

Volatile organic compounds (VOCs) are defined as organic compounds with vaper pressure $>0.01 \mathrm{KPa}$ at $293.15 \mathrm{~K}$ (Iluțiu - Varvara et al., 2013). Exposure to VOCs may causes serious health effects such as skin, cardiovascular, eyes, liver, kidneys, gastrointestinal, respiratory system and central nervous system diseases. Additionally, VOCs are one of the 
major contributors of the ozone formation, and subsequently photochemical smog.

High concentration of VOCs has been measured in all points, ranging from 324.09ppb in the loading area to $645.2 \mathrm{ppb}$ in the casting area (Figure 3), indicating an increase by $39 \%$ and $177 \%$ in comparison with the ambient atmosphere (233ppb). Concentration of VOCs and other pollutants in the ambient atmosphere is attributed to the effect of the industrial city where the plant is located there. The most probable sources of VOCs in EAF process are: hydrocarbons contained in the scrap materials (plastic, paints, and foams), degreasing and decarburization of scrap, charging, tapping and slag pouring (Iluțiu - Varvara et al., 2013). In this study, scrap materials might be the main source of emissions, while less VOCs are produced during EAF operation. During cooling process, water spraying results in highly alkaline fumes which may causes serious air pollution (Iluţiu - Varvara et al., 2016). VOCs compounds consisting of tens of the organic compounds, so there is no specific limit for it, while there are many guidelines for some compounds such as benzene and formaldehydes.

Similarly, Iluţiu-Varvara et al.(2016), reported high concentration of VOCs in the melting stage in the EAF ranged from 2183ppm to 23368ppm from furnaces with capacity of 10 and $30 \mathrm{t}$ respectively, and the emissions increased with time up to 110 minutes, and then deceased significantly with time (Iluțiu - Varvara et al., 2013). Odabasi, et al. (2009), found that the concentration of the organic compounds from the stack of steel plants with arc furnace technology, reached up to 611,165000 , and $33 \mathrm{ng} / \mathrm{m} 3$ for polycyclic aromatic hydrocarbons (PAHs), polychlorinated biphenyls (PCBs), and polybrominated diphenyl ethers (PBDEs) respectively (EC, 2018). Similarly, Gomes (2016) reported high VOCs emissions form steel production units having electric arc furnaces.

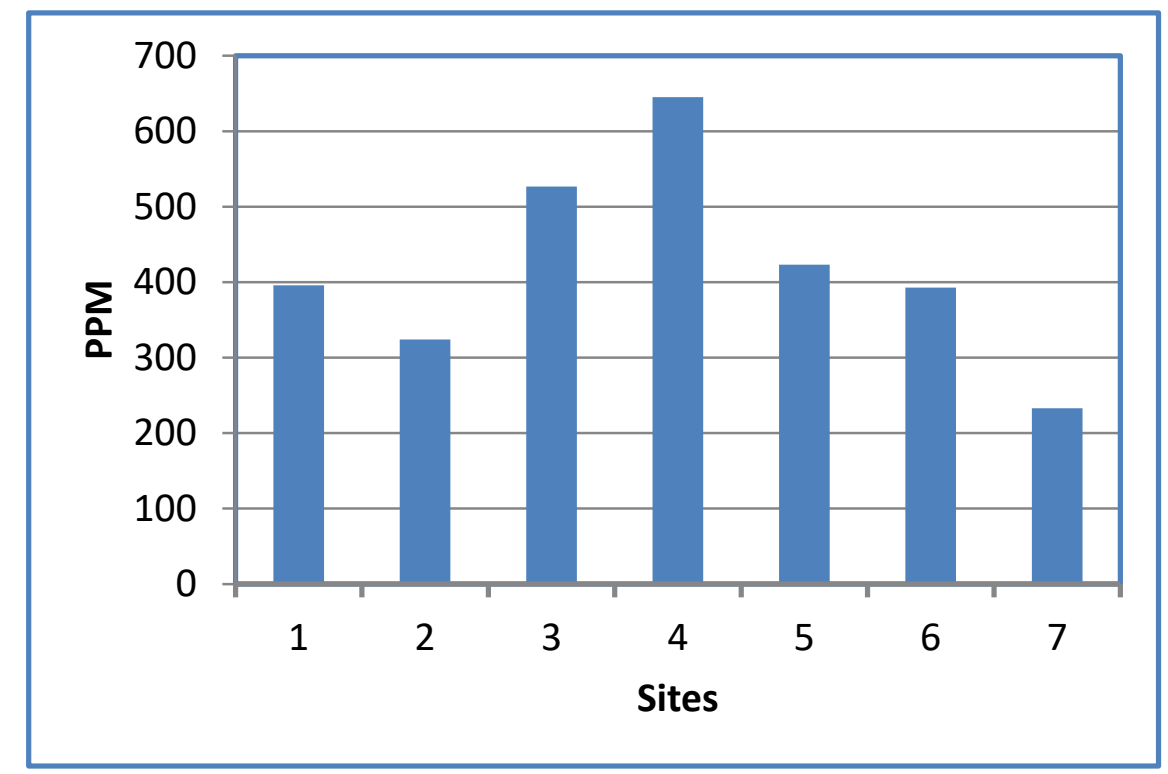

Figure 3. VOCs concentration

\subsection{Concentration of Carbon Oxides}




\section{Macrothink}

While $\mathrm{CO}_{2}$ is considered the major contributor in climate change, $\mathrm{CO}$ has serious health effects forming carbon carboxyhemoglobin (COHB) resulting initially in symptoms of headache, nausea, dizziness, vomiting (at $\mathrm{COHB}=10 \%$ ). Prolonged or high exposure period may causes coma and collapse $(\mathrm{COHB}=40 \%)$, and it is lethal at COHB level of 50-60\%. To maintain $\mathrm{COH}<2.5 \%$, WHO recommended $\mathrm{CO}$ concentration to be $90,50,25$, and 10ppm for exposure time of $15 \mathrm{~m}, 30 \mathrm{~m}, 60 \mathrm{~m}$, and 8 hours respectively (Odabasi et al., 2009). OSHA standard limited TWA of $\mathrm{CO}_{2}$ in workplace at 5000 ppm (WHO, 2000).

The concentration of $\mathrm{CO}$ was zero in all measure points. This could be explained by the high temperature of steel making process resulted in complete combustion and converting of $\mathrm{CO}$ to $\mathrm{CO}_{2}$. In contrast, high $\mathrm{CO}_{2}$ concentration was detected in all points ranged from $356 \mathrm{ppm}$ at slag pouring area to 410ppm at the casting area as shown in Figure 4. In comparison with the ambient air (317ppm), CO2 inside the plant increased by 70, 39, 126, 177, 82, and $69 \%$ for the measured points respectively. Also high concentration was measured at the melting area (398ppm). Iluțiu - Varvara, et al. (2015), reported that the highest COx level inside the EAF occurred at the melting and at the beginning of the refining stage (EPA, 2009a). During melting and refining process, carbon is removed from the raw materials and converted to $\mathrm{CO} 2$, which explains the high concentration at the melting and casting areas. Also, Argon-oxygen decarburization (AOD) process is a significant source of $\mathrm{CO} 2$ generation. In AOD, Argon increases the affinity of carbon to $\mathrm{O} 2$ resulted in high carbon removal and high oxides formation. At these concentrations of $\mathrm{CO}$ and $\mathrm{CO}_{2}$ there is no occupational health effect is expected.

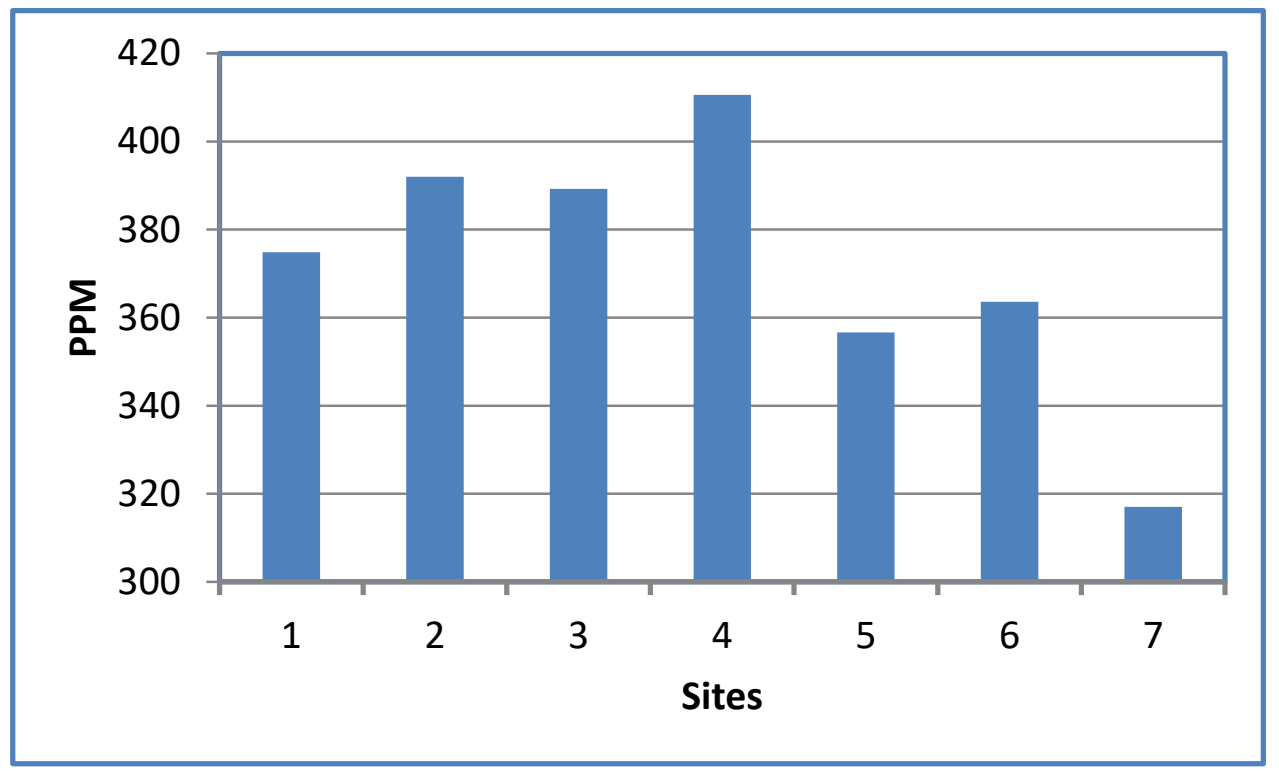

Figure 4. $\mathrm{CO} 2$ concentration

\subsection{Concentration of $\mathrm{O3}$}

While, chemical reaction of NOx, VOCs and sunlight is the major source of Ozone, it can 


\section{Macrothink}

also be generated from many industries particularly the iron and steel industries. Environmentally, ozone is mainly responsible for photochemical smog formation. From the point of view health effect, it causes skin, eyes, nose and throat irritation, headache, vomiting, reduce lung function, inflame and damage cells that line lungs, aggravate asthma, and may cause permanent lung damage (Iluțiu - Varvara et al., 2015).

The concentration of $\mathrm{O}_{3}$ in the steel making plant ranged from 0.026 at the casting area to $0.156 \mathrm{ppm}$ in the cooling area while it was 0.01 in the ambient atmosphere (Figure 5). Ozone formation depends on NOx and VOCs, so positive concentration was detected in all points. Usually the point with the higher NOx and VOCs level is the higher $\mathrm{O}_{3}$, however this is not totally true because there is another factor affecting ozone formation i.e. the sunlight. Lower concentrations were measured in the covered area (melting, casting) where there is no sunlight which is necessary for $\mathrm{O}_{3}$ formation, while high concentration was measured at the area exposed to sunlight (cooling).

In comparison with OSH standards of $0.1 \mathrm{ppm}$ as an average over $8 \mathrm{hrs}$, the concentration s of ozone in the workplace has no health effect.

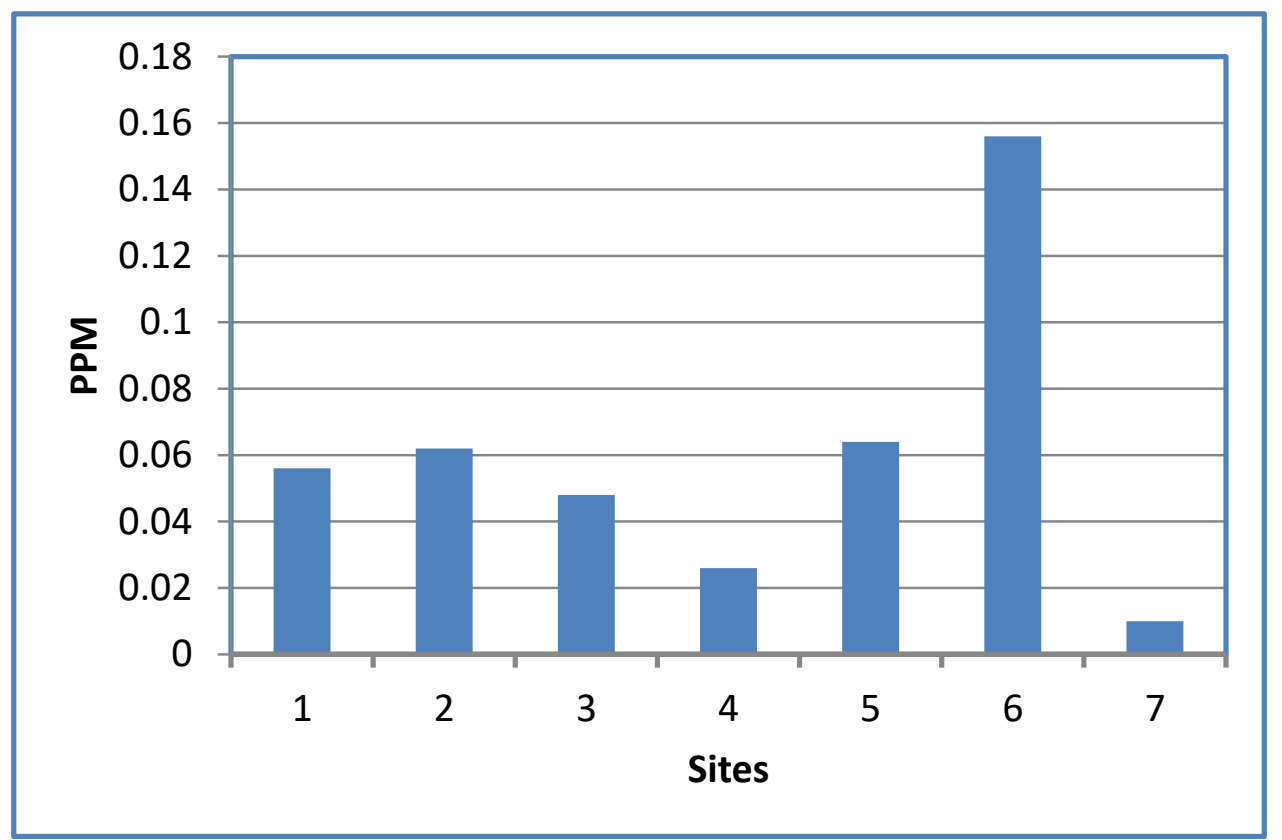

Figure 5. O3 concentration

\subsection{Concentration of $P M 1_{0}$ and $P M_{2.5}$}

In steel making, dust is generated in different process, starting from storage of raw materials, handling, loading, charging, and melting, with lower level form next process. Dust is formed during the melting process. Typically, around $10 \mathrm{~kg}$ of dust generates per one ton of liquid steel (EPA, 2009b). Usually, dust contains many contaminants mainly iron oxides, calcium oxide, and zinc oxide. Additionally, dust may contain significant level of heavy metals such as: $\mathrm{Al}, \mathrm{Cd}, \mathrm{Cr}, \mathrm{Ni}, \mathrm{Co}, \mathrm{Cu}$ and $\mathrm{Pb}$. 


\section{Macrothink}

The level and contents of the fugitive dust strongly depends on the scrap composition and types, furnace additives, efficiency of the control devices, and the measurements taken during storage and handling.

Survey of dust level indicated that the high concentration of $\mathrm{PM}_{10}$ and $\mathrm{PM}_{2.5}$ were measured at the furnace area, reached 479 and $182 \mu \mathrm{g} / \mathrm{m}^{3}$ for both contaminants respectively (Figure 6, $7)$. Lower concentration were found in the slag area through pouring process $(294,25)$, also in the scrap area $(195,32)$ resulted from the handling and segregation process. Very low concentrations were measured in the loading area $(28,3)$, casting $(17,7)$ and cooling area $(15$, 1) where no source of dust emissions. Health effect of dust particularly depends on its constituent. WHO recommended PM10 in the ambient air at 50 and $20 \mu \mathrm{m} / \mathrm{m}^{3}$ and for PM2.5 at 10 and $25 \mu \mathrm{m} / \mathrm{m}^{3}$ for 24-hours and annual mean respectively (Battle et al., 2014). In the scrap area, furnace area and the slag area, the concentration of PM10 and PM2.5 exceeded WHO daily allowable limits for ambient air. The health effects of particulate matters $\left(\mathrm{PM}_{10}\right.$ and $\mathrm{PM}_{2.5}$ ) are well documented, and there is no evidence of a safe level of exposure or a threshold below which no adverse health effects occur (WHO, 2005). For example, 3\% of cardiopulmonary and 5\% of lung cancer deaths are attributable to PM globally, and an increase in PM10 by $10 \mu \mathrm{g} / \mathrm{m}^{3}$ will cause an increase in daily motility by $0.2-0.6 \%$. The same increase $\left(10 \mu \mathrm{g} / \mathrm{m}^{3}\right)$ in $\mathrm{PM}_{2.5}$ will increase the mortality by $6-13 \%$ (WHO, 2005). It can be concluded that the high concentration of dust in the steel plant may cause high risk to the workers' health.

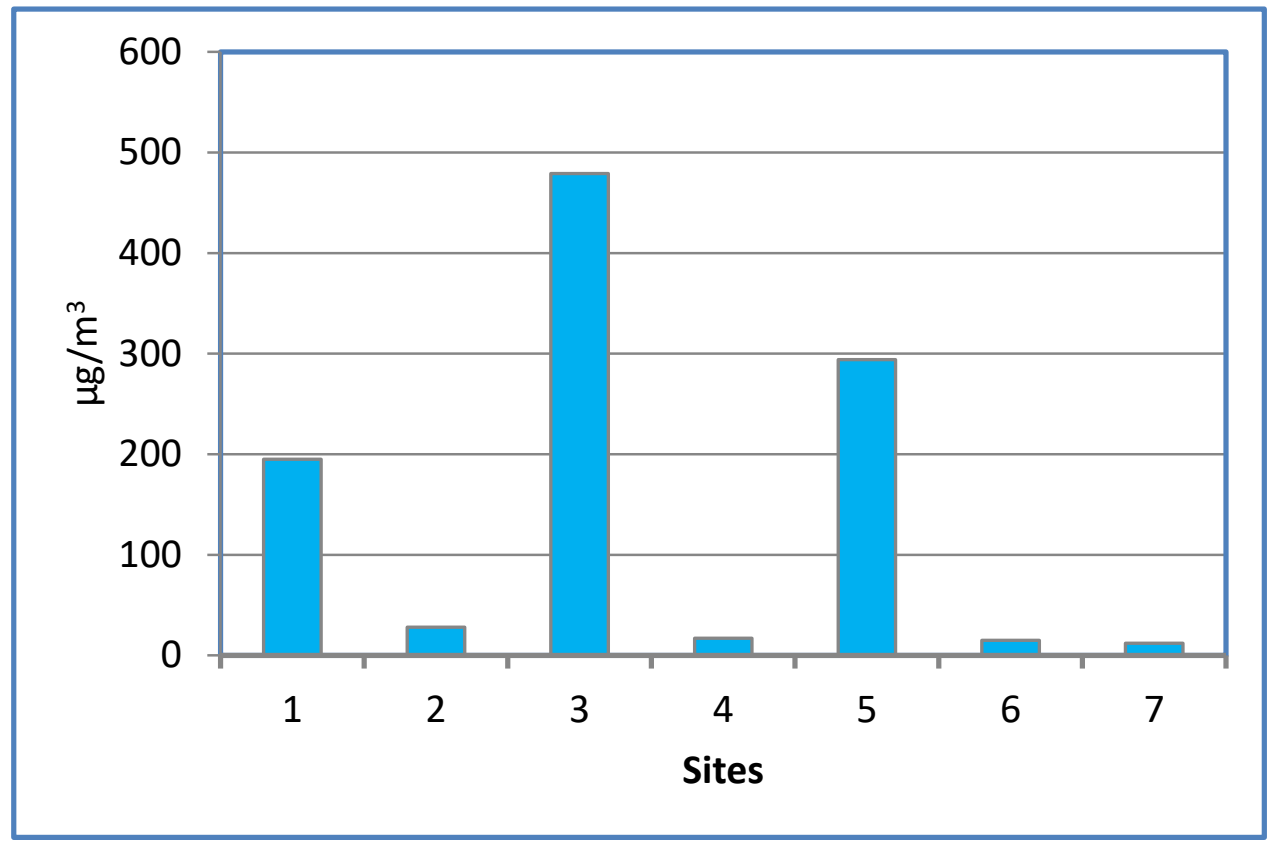

Figure 6. PM10 concentration 


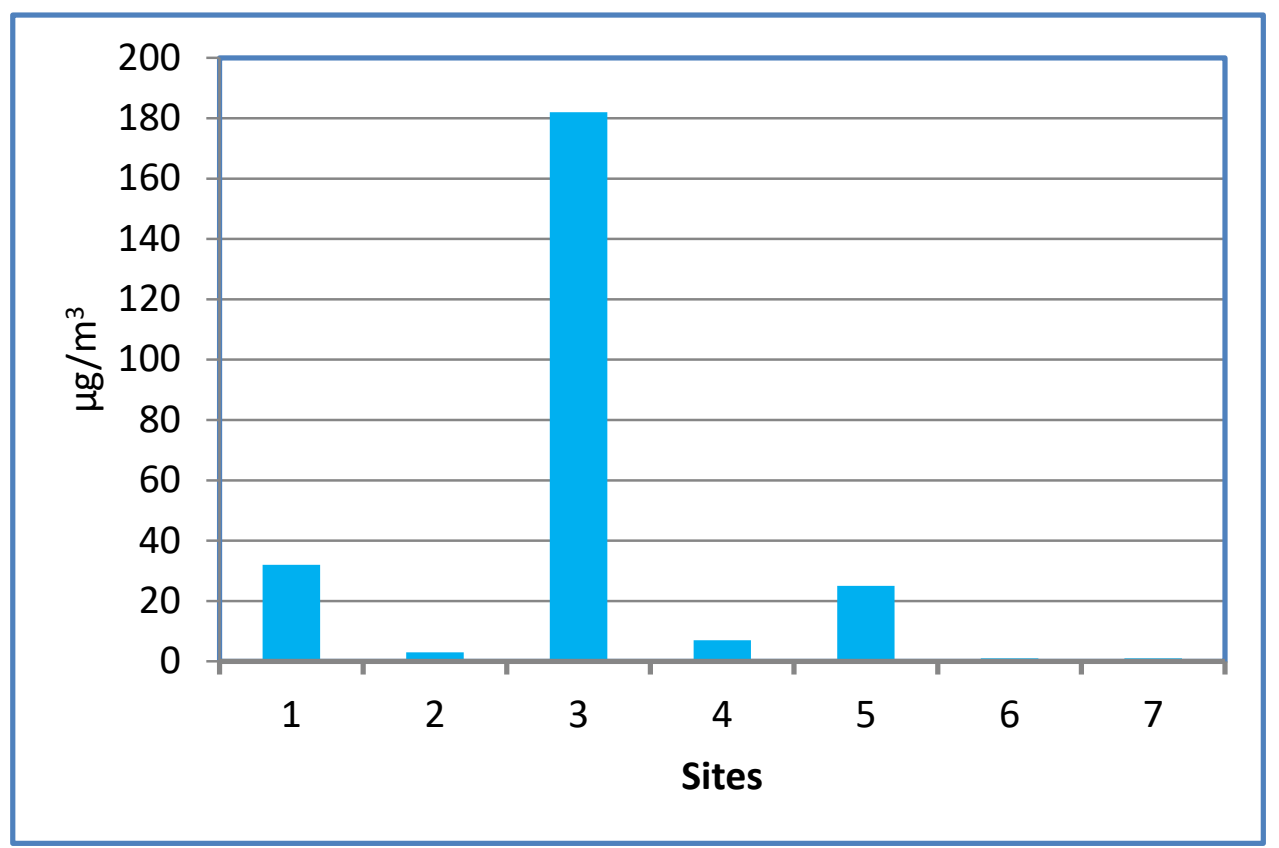

Figure 7. PM2.5 concentration

\section{Conclusions}

Indoor air quality in a steel making industry was evaluated through measurements of gases and particulate matters. The results obtained showed high concentration of indoor gases in comparison with the ambient air. High concentration of $\mathrm{PM}_{0}$ and $\mathrm{PM}_{2.5}$ may cause potential health effect on workers. Types and contamination of scrap, performance of the control devices, environmental measurements are the key parameters in pollution reduction. Good ventilation and the atmospheric connection with the surrounding environment reduced the concentrations of pollutants inside the plant, and increase them in the environment. To reduce potential impacts on workers' health and the environment, it is recommended to:

1. Set a periodic medical check for workers especially lungs function.

2. Enforce workers to wear PPE.

3. Undertake industrial hygiene studies in order to evaluate the long-term effects of steel industries on human health.

4. Selection of uncontaminated scrap materials to be used in the industry.

5. Install adequate pollution control devices associated with routine maintenance.

\section{Conflict of Interest}

The authors certify that they have no affiliations with or involvement in any organization or entity with any financial interest, or non-financial interest in the subject matter or materials discussed in this manuscript. 


\section{References}

Al-Zboon, K. (2017). Indoor Air Pollution Due to Household Use of Olive Cake as a source of energy. IJEWM, 19(3), 248-267. https://doi.org/10.1504/IJEWM.2017.10005194

Alharbi, B. H., Pasha, M. J., \& Tapper, N. (2014). Assessment of Ambient Air Quality in Riyadh City, Saudi Arabia. Current World Environment, 9(2), 227-236. https://doi.org/10.12944/CWE.9.2.01

Chaurasia, S., \& Tiwari, A. (2016). Assessment of Ambient Air Quality in the Vicinity of Cement Industries. International Journal of Applied Research and Technology, 1(1), 39-46.

Awad, A. H. A., Shakour, A. A., Ibraheim, Y. H., \& Abdel-Latif, N. (2016). Air Quality Index for Makkah City, Saudi Arabia: Recommended Breakpoints and Bands. International Journal of ChemTech Research, 9(6), 552-559.

Battle, T, Eric, H, Holappa, L, Jalkanen, H, Kitamura, S, Louhenkilpi, S, ... Yang, Y. (2014). Treatise on Process Metallurgy, Vol 3: Industrial Processes: Part A Ferrous Process Metallurgy. $1^{\text {st }}$ ed. Elsevier, Amsterdam, 530p.

Chan, E., Riley, M., Thomson, M. J., \& Evenson, E. J. (2004). Nitrogen Oxides (NOx) Formation and Control in an Electric Arc Furnace (EAF): Analysis with Measurements and Computational Fluid Dynamics (CFD) Modeling. ISIJ International, 44(2), 429-438. https://doi.org/10.2355/isijinternational.44.429

DEEDI, Department of Employment, Economic Development and Innovation, Queenlands government. Health effects of nitrogen oxides. c2018. [Online] Available: https://www.dnrm.qld.gov.au/_data/assets/pdf_file/0020/212483/2-health-effects-of-nitrogen -dioxide.pdf

EC, European Commission, Integrated Pollution Prevention and Control (IPPC), Best Available Techniques Reference Document on the Production of Iron and Steel, c2018(accessed 16/6/2018). [Online] Available:

http://eippcb.jrc.ec.europa.eu/reference/BREF/IS_Adopted_03_2012.pdf

Echterhof, T.., \& Pfeifer, H. (2011). Measurement and Control of NOx Emissions at Two AC Electric Arc Furnaces. ISIJ International, 51(10), 1631-1636.

https://doi.org/10.2355/isijinternational.51.1631

El-Sharkawy, M. F., \& Noweir, M. E. H. (2014). Indoor air quality levels in a University Hospital in the Eastern Province of Saudi Arabia. Journal of Family and Community Medicine, 21(1), 39-47. https://doi.org/10.4103/2230-8229.128778

EPA (2009a). Technical Support Document For The Iron And Steel Sector: Proposed Rule For Mandatory Reporting Of Greenhouse Gases. c2018. [Online] Available: https://www.epa.gov/sites/production/files/2015-02/documents/tsd_iron_and_steel_epa_9-8-0 8.pdf

EPA (2009b). Ozone and Your Health, c2018. [Online] Available: 
https://www3.epa.gov/airnow/ozone-c.pdf.

EPRI (2000). Electric Power Research Institute (EPRI). Indoor Air Quality Issues for Foundries. c2018. [Online] Available:

http://www.energy.ca.gov/process/pubs/air_quality_issues.pdf.

Gomes, J. (2016). Emission of high toxicity airborne pollutants from electric arc furnaces during steel production. In "Ironmaking and Steelmaking Processes Greenhouse emissions control and reduction", Cavaliere, P. Editor, Springer International Publishing AG, Cham.

Hamzah, N. A., Shamsul, B. M. T., \& Noor, H. I. (2016). Metal dust exposure and lung function deterioration among steel workers: an exposure-response relationship. Int J Occup Environ Health, 22(3), 224-232. https://doi.org/10.1080/10773525.2016.1207040

Iluţiu-Varvara, D. A., Brânduşan, L., \& PICĂ, E. M. (2013). Researches Regarding the Air Pollution with Sulfur Dioxide (SO2) to the Steelmaking. Advanced Engineering Forum, 8-9, 116-126.

Iluțiu-Varvara, D. A., Carmen, M. M., \& Ioana-Monica, S. B. (2015). The Assessment and reduction of carbon oxides emissions at Electric Arc Furnaces for sustainable development. Procedia Technology, 19, 402-409. https://doi.org/10.1016/j.protcy.2015.02.057

Iluțiu-Varvara, D. A., Carmen, M. M., Claudiu, A., Adriana, H., Florin, V. D., Ioana-Monica, S. B., \& Adriana, M. M. (2016). An Assessment of Pollution with Volatile Organic Compounds in the Electric Arc Furnaces. Procedia Technology, 22, 452-456. https://doi.org/10.1016/j.protcy.2016.01.086

Jiang, X. Q., Mei, X. D., \& Feng, D. (2016). Air pollution and chronic airway diseases: what should people know and do. J Thorac Dis, 8(1), 31-40.

Jena, P. K., Behera, D. K., Mishra, C. S., \& Mohanty, S. K. (2011). Assessment of air quality in and around a steel industry with direct reduction iron route. Journal of Environmental Science and Engineering, 53(4), 437-442.

Khullar, M., \& Gupta, P. (2017). An Assessment of Indoor Air Quality (IAQ) in Metal industries of Delhi. International Journal of Environment, Agriculture and Biotechnology, 2(1), 539-544. https://doi.org/10.22161/ijeab/2.1.67

Kirschen, M., Lukas, V., \& Herbert, P. (2005). NOx emission from electric arc furnace in steel industry: Contribution from electric arc and co-combustion reactions. Clean Techn Environ Policy, 7(4), 236-244. https://doi.org/10.1007/s 10098-005-0010-y

Muhamad-Darus, F., Azni, Z. A., \& Mohd, T. L. (2011). Preliminary Assessment of Indoor Air Quality in Terrace Houses. Health and the Environment Journal, 2(2), 8-14.

Odabasi, M., Abdurrahman, B., Tolga, E., Remzi, S., Yetkin, D., Ayse, B., .. Banu, C. (2009). Electric Arc Furnaces for Steel-Making: Hot Spots for Persistent Organic Pollutants. Environ. Sci. Technol, 43(14), 5205-5211. https://doi.org/10.1021/es900863s

Salama, K. F., \& Berekaa, M. M. (2016). Assessment of air quality in Dammam slaughter 


\section{Macrothink}

Environmental Management and Sustainable Development

ISSN 2164-7682

2019, Vol. 8, No. 1

houses, Saudi Arabia. International Journal of Medical Science and Public Health, 5(02), 287-291. https://doi.org/10.5455/ijmsph.2016.10092015121

Shutt, R. H., Lisa, M. K., Scott, W., Premkumari, K., Renaud, V., Errol, M. T, ... Robert, D. (2017). Exposure to air pollution near a steel plant is associated with reduced heart rate variability: a randomised crossover study. Environ Health, 16(1).

https://doi.org/10.1186/s12940-016-0206-0

SWU, Safe Work Australia. Workplace Exposure Standards For Airborne Contaminants, c2018. [Online] Available:

https://www.safeworkaustralia.gov.au/system/files/documents/1804/workplace-exposure-stan dards-airborne-contaminants-2018_0.pdf

UKSTEEL. The Steel Industry. C2018. [Online] Available:

http://www.eef.org.uk/uksteel/About-the-industry/default.htm

WSA, World steel Association, Steel Statistical Yearbook 2017,

https://www.worldsteel.org/en/dam/jcr:3e275c73-6f11-4e7f-a5d8-23d9bc5c508f/Steel+Statist ical+Yearbook+2017.pdf

Valenti, C., Paolo, P., Alessandra, B., Roberto, M., Paolo, B., ... Roberto, B. (2016). Respiratory illness and air pollution from the steel industry: the case of Piquiá de Baixo. Brazil (Preliminary report) Multidiscip Respir Med., 11, 41.

https://doi.org/10.1186/s40248-016-0077-9

WHO (2000), Air Quality Guidelines-Second Edition, Chapter 5.5 Carbon monoxide. c2018. [Online] Available:

http://www.euro.who.int/_data/assets/pdf_file/0020/123059/AQG2ndEd_5_5carbonmonoxi de.PDF

WHO (2005). Air quality guidelines for particulate matter, ozone, nitrogen dioxide and sulfur dioxide. c2018. [Online] Available:

http://apps.who.int/iris/bitstream/handle/10665/69477/WHO_SDE_PHE_OEH_06.02_eng.pd f;jsessionid=A8830271E60890A8D0477BDA95E178D6? sequence $=1$

\section{Copyright Disclaimer}

Copyright for this article is retained by the author(s), with first publication rights granted to the journal.

This is an open-access article distributed under the terms and conditions of the Creative Commons Attribution license (http://creativecommons.org/licenses/by/3.0/). 